\title{
Stakeholder Influences and Environmental Management Practices in Fleet Operations - A Research Agenda
}

\author{
Thoo Ai Chin ${ }^{1, a}$ and Tan Lay Jie ,b $^{\text {,b }}$ \\ ${ }^{1}$ Faculty of Management, Universiti Teknologi Malaysia, 81310 Skudai, Malaysia \\ ${ }^{2}$ Faculty of Management, Universiti Teknologi Malaysia, 81310 Skudai, Malaysia \\ aacthoo@utm.my, 'layjietan90@gmail.com
}

\begin{abstract}
Keywords: Stakeholder influences, Environmental management practices, Fleet operations
\end{abstract}
\begin{abstract}
Relationship between stakeholder influences and environmental management practices has not yet received sufficient attention in academic research in Malaysian fleet operations. Due to the increased awareness and concern among stakeholders for environmentally friendly business processes, the two main stakeholder influences including regulatory pressures and customer pressures are considered in combination to ensure firms to behave ethically and socially responsible. Environmental management practices including effectiveness of policy, effectiveness of implementation and effectiveness of planning in environmental management are one of the effective ways of dealing with environmental risks and costs. However, there is a little empirical research on how practitioners define and incorporate stakeholder influences into overall environmental management practices, particularly in the context of fleet operations. As such, this paper proposes a model to include two stakeholder influences and three environmental management practices. It is expected that this paper will offer useful guidance for future research scholars to empirically examine the relationship between stakeholder influences and environmental management practices for sustained business performance.
\end{abstract}

\section{Introduction}

A corporate stakeholder can affect or is affected by the objectives, policies and actions of a business as a whole [1]. Freeman [2] defined that stakeholder as people who influence the achievement of an organization's goal. The key stakeholders encompass shareholders, employees, suppliers, customers, distributors, government bodies, competitors, creditors, media, unions and the community from which the firm acquires its resources. In today's dynamic business environment, stakeholders have posed numerous influences on company business activities as social responsibility and sustainability have been integrated into traditional business management processes and systems [3]. Therefore, it is critical for firms to successfully manage and serve the interests of stakeholders efficiently in order to keep a long term business success and sustainability [4].

Business activities can pose a significant threat to the environment in terms of carbon monoxide emissions, discarded packaging materials, scrapped toxic materials, traffic congestion and other forms of industrial pollution [5]. In many countries, the business activities of fleet operations are responsible for a large proportion of air pollution. Fleet operations include the management of corporate diesel vehicles such as trucks, buses and cars for the purpose of transporting people or goods from one location to another [6]. In Malaysia, one of the air pollution problems is originated from vehicle emission (70\% 75\%) [7] [8]. According to Department of Environment Malaysia in 2009 , the overall air pollutant emission is nearly 1.6 million metric tons of carbon monoxide (CO); 756,359 metric tons of nitrogen dioxide $\left(\mathrm{NO}_{2}\right)$ and 27,727 metric tons of particulate matter (PM) [9]. The emissions from millions of vehicles can cause chronic health problems such as shortness of breath, damage to lung tissues, coughing, lung and heart disease, asthma, influenza and mortality [6]). In order to reduce the emission of air pollutions from vehicles, Malaysian government plays a major role in implementing several measures such as adoption of EURO 2M specification [8], regulating the use of specially designed catalytic converters, improving combustion efficiency [10], 
enforcing the Smoke Regulations under the Motor Vehicles (Control of Smoke and Gas Emission) Rules 1977 and ensuring vehicles to conduct more rigorous maintenance and inspection [11].

Businesses operate in several interrelated pressures from internal and external stakeholders: government, society, shareholders, customers and market when respond to environmental matters such as conserving materials, reduced water and energy use. Most of the stakeholders expect their corporations to behave ethically and socially responsible. An empirical study by Wolf [12] found that stakeholder pressure contributes to an organization's sustainability performance. Thus, it is justifiable for today's firms to recognize and acknowledge the interest of its variety of stakeholder groups when making business decisions and embracing environmental management practices. The following sections discuss two major stakeholders' pressures including regulatory pressures and customer pressures.

\section{Regulatory Pressures}

Many governments enact legal mandates that restrict organizations to use pollution control technology, set pollution thresholds and report their pollution emissions [13]. The threat of regulatory pressures may motivate firms to work harder to implement many green or sustainable business initiatives [14]. If organizations fail to fulfill the regulatory requirements, they might lose their operating permits and end up paying fines and penalties in term of money. Therefore, the fear of legal sanction is considered to be the main reason why organizations implement proactive environmental activities [13] [14] [15]. Nevertheless, regulatory pressures create business opportunities for competitive advantage. Companies that follow stricter regulatory requirements benefitted from cost savings, better public image and decreased environmental liability [5]. If many firms implement the green practices, new environmental regulations are becoming a less relevant pressure, in turn, mandated reporting requirements can be reduced and the needs to purchase and install costly pollution control technologies can be eliminated as well. In fact, government is the primary corporate stakeholder for the types of disclosures a firm should make [6].

\section{Customer Pressures}

Customer is of paramount importance to business success. Firms respond to customer requirements and needs when customers are involved in reference groups to provide suggestions for their products. The company's dependency on customer is the key mechanism through which standards of quality management have dispersed [16]. Customers' environmental awareness can be a strong commercial reason for firms to be environmentally friendly. According to Uchida and Ferraro [14], customer concern is the second most important pressure for firms to adopt an environmental management plan, after government pressure. This creates a competitive advantage for companies worldwide to enhance profitability, access to new market, strengthen customer relationships and gain competitive edge. Therefore, some firms may also mimic environmental practices that successful leading firms have adopted.

\section{Environmental Management Practices in Fleet Operations}

An increasing concern and awareness among the general public for environmentally friendly business processes and prevention of global warming can trigger firms to show remarkable commitment to green practices such as recycle, reuse and reduce materials. In actuality, corporations react actively towards social values can achieve a social image and social legitimacy for their long-term survival and competitiveness [13]. In support, Uchida and Ferraro [14] found that firms combine environmental and organizational practices can create a competitive advantage to enhance profitability, access to new market, strengthen customer relationships and gain competitive edge. As such, some firms may also mimic environmental management practices that successful leading firms have adopted. For the purpose of this paper, environmental management 
practices in fleet operations are drawn directly from Wong and Fryxell [6] and reviewed from effectiveness of policy, effectiveness of implementation and effectiveness of planning.

\section{Effectiveness of Environmental Policy}

An environmental policy is a written statement to provide a formal establishment of environmental objectives and targets. Effective environmental policy is fundamental to the firm's survival and should be documented and maintained. In order for environmental policy to be effective, the environmental policy should demonstrate commitment by senior management, communicate to all employees and be accessed by public easily. It is imperative that the commitment of top management to prevent operational pollution and continually improve firm operation in order to stay legally compliant [6]. In addition, policy statement triggers higher top management participation and motivates firms to seek environmental certification for complying relevant environmental legislation and regulations.

\section{Effectiveness of Implementation}

The establishment and maintenance of documented procedures are critical to identify the environmental aspects of an organization's activities and the relevant legal requirements. Most importantly, the environmental objectives and targets should be periodically reviewed and consistent with the environmental policy. The broad range methods of environmental implementation requires firm to maintain document and operational control, procedures for handling environmental records, documentation to describe the core elements of the management system, procedures for handling nonconformance and taking corrective and preventive action, procedures to monitor and measure key characteristics, internal and external communication on significant environmental aspects, procedures for periodic environmental management system audits, emergency preparedness and response procedures. In addition to the legal requirements, it is necessary for firm to consider the views of key stakeholder groups that carry weight in firm environmental activities. Finally, firms need to have effective environmental programs in place to assign roles and responsibilities for relevant functions and set a target to complete the programs within the time frame [6]. According to Zeng et al. [17] many organizations are actively involved in environmental protection for quality execution and certification including documentation, executing procedure, checking, controlling forms and other paper work.

\section{Effectiveness of Planning}

Managers should participate in the strategic planning activities such as internal and external assessment of environment including past performance, internal capabilities, regulatory issues, supplier trends and customer preference. To better fulfill the planning objectives, organization needs to improve its resource allocation, increase customer satisfaction and enhance management development. Similarly, Lee at al. [18] stated that effectiveness of environmental planning consists of planning alignment, planning capability and planning objectives. The study found that competitive pressure and top management support are important in effectiveness of environmental planning.

In addition, the effectiveness of environmental planning should include recognizing training needs and providing proper training to all personnel that could have a significant impact on the environment. Also, an effective environmental management planning requires sufficient resources for various implementations as well as the appointment of a management representative to continual monitor all aspects of environmental management system and report to top management. Towards the end of the each planning cycle, top management should conduct periodic management reviews, take corrective actions such as reformulate objectives and targets, procedures and environmental policy to mitigate the causes of environmental nonconformance and improve environmental preservation [6]. 


\section{Conclusions}

Given that there has been limited literature about how much a firm's environmental management practices are influenced by stakeholder pressures, it is important to note that the success of fleet operations corresponds to their ability to match the expectations of stakeholders and adoption of environmental management practices. This paper is the first to propose these two influences of stakeholders in combination (regulatory pressures and customer pressures) and in the case of environmental management practices for the first time in Malaysian fleet operation context. Therefore, future research is needed to empirically examine the relationship between stakeholder influences and environmental management practices in fleet operation. In conclusion, besides attaining economic goals, Malaysian fleet operations must not forget to develop environmental management system, fulfill stakeholders demand and meet government compliances as the pressures of stakeholders have been empirically proven in contributing to organizational sustainability performance.

\section{References}

[1] A. B. Carroll, Business and Society: Ethics and Stakeholder Management, second ed., Cincinnati, OH, South-West Publishing, 1993.

[2] R. E. Freeman, Strategic Management: A Stakeholder Approach, United States of America, Cambridge University Press, 2010.

[3] S. de Colle, C. Gonella, Corporate Social Responsibility: The Need for an Integrated Management Framework, International Journal of Business Performance Management. 5(2003) 199-212.

[4] S. P. Hermann, Stakeholder Based Measuring and Management of CSR and Its Impact on Corporate Reputation, in: M. Huber, S. O'Gorman (Eds.), From Customer Retention to a Holistic Stakeholder Management System: Living a Vision, Springer-Verlag Berlin Heidelberg, Leipzig, 2008, pp. 51-61.

[5] J. D. Wisner, K-C. Tan, G. K. Leong, Supply Chain Management: A Balanced Approach, third ed., Canada, South-Western Cengage Learning, 2012.

[6] L. T. Wong, G.E. Fryxell, Stakeholder Influences on Environmental Management Practices: A Study of Fleet Operations in Hong Kong (SAR), China, Transportation Journal. 43(2004) 22-35.

[7] R. Afroz, M. N. Hassan, N. A. Ibrahim, Review of Air Pollutant and Health Impact in Malaysia, Environmental Research. 92(2003) 71-77.

[8] A. M. Abdullah, M. A. A. Samah, Y. J. Tham, An Overview of the Air Pollution Trend in Klang Valley, Malaysia, Open Environmental Sciences. 6(2012) 13-19.

[9] M. Maizatun, Z. S. A. K. Sharifah, S. Azlinor, With Climate Change Through Air Pollution Control: Some Legal Initiatives From Malaysia, International Conference on Environment, Energy and Biotechnology IPCBEE, 33, IACSIT Press, Singapore, 2012.

[10] Information on http://www.met.gov.my/index.php?lang=english

[11] Information on http://www.kkr.gov.my/files/akta_subsidiari/9.pdf

[12] J. Wolf, The Relationship Between Sustainable Supply Chain Management, Stakeholder Pressure and Corporate Sustainability Performance, Journal of Business Ethics. 119(2014) 317-328.

[13] A. J. Hoffman, Institutional Evolution and Change: Environmentalism and the U.S. Chemical Industry, The Academy of Management Journal. 42(1999) 351-371. 
[14] T. Uchida, P. J. Ferraro, Voluntary Development of Environmental Management Systems: Motivations and Regulatory Implication, Journal of Regulatory Economics. 32(2007) 37-65.

[15] A. Lindblom, J. Ohlsson, Stakeholders' Influence on the Environmental Strategy of the Firm: A Study of the Swedish Energy Intensive Industry. Dissertation in TPA Halmstad University, Sweden, 2011.

[16] S. W Anderson, J. D. Daly, M. F. Johnson, Why Firms Seek ISO 9000 Certification: Regulatory Compliance or Competitive Advantage, Production and Operations Management. 8(1999) 28-43.

[17] S. X. Zeng, V. W. Y. Tam, K. N. Le, Towards Effectiveness of Integrated Management Systems for Enterprises, Engineering Economics. 21(2010) 171-179.

[18] G-G. Lee, H-F. Lin, J-C. Pai, Influence of Environmental and Organizational Factors on the Success of Internet-based Interorganizational Systems Planning, Internet Research. 15(2005) 527543. 